\section{Humus and the Farmer}

Under this title, Mr. G. V. Jacks, deputy-director of the Imperial Bureau of Soil Science, Rothamsted, delivered a lecture on February 12 to the Royal Society of Arts, in which he dealt with the origin of humus, its functions in the soil, and how far shortage of humus-producing organic manures can be made good by other means. Humus is derived from decaying plant and animal residues; it acts by promoting a granular structure in the soil, by supplying energy to micro-organisms, and by providing plant nutrients. In the natural state, vegetation supplies the kind of humus in which it best thrives, but cultivated crops do not supply such an optimum product, so that human intelligence and skill are needed to bring about that biological balance in the soil which is the essence of fertility. A grass cover is especially valuable for producing the granular soil structure that is needed by our basic crops, for these are also grasses, perennial for animal and annuals (cereals) for human consumption.

When a soil has lost its virginal fertility by longcontinued arable husbandry, it is best rejuvenated by laying it down to grass for a shorter or longer period. When our ancestors first enclosed the open fields, they nearly always put them down to pasture. Later, when clovers and roots were introduced, mixed farming became possible, animals could be kept throughout the winter and their manure conserved for the land. To-day much stress is laid on the necessity for rejuvenating our cultivated soils by ley farming or alternate husbandry. But the use of grass and plant and animal residues does not suffice in the absence of human skill and intelligence. These attributes became manifest when drilling was first substituted for broadcasting seed, when the art of drainage was developed, and when artificial fertilizers were invented. Such fertilizers can provide all the nutrients plants require, though they cannot produce the granular soil structure effected by humus. Plant humus, on the other hand, will not make a soil fit for permanent agriculture, for a human society makes far greater demands on the soil than does any natural plant community ; nevertheless, every scrap of waste organic matter which the land preduces should be returned to it.

\section{Soviet Agriculture}

IT is stated by "Russia Today" Press Service that the average annual grain crop in the U.S.S.R. for 1937, 1938 and 1939, notwithstanding the severe droughts in the two latter years, amounted to more than 100 million tons, exceeding the 1913 harvest, the best in pre-revolutionary Russia, by one third. The grain crop of 1940 amounted approximately to $112 \frac{1}{2}$ million tons. There are 243,000 collective farms in the Soviet Union, embracing $18,800,000$ peasant households, or 94 per cent of the total number of peasant households in the country. The Soviet Government has handed over to the collective farms for their free use in perpetuity 940 million acres of land, which represents an average of 50 acres per household. It is estimated that Soviet agriculture employs more than half a million tractors, nearly 170,000 harvester-combines and 200,000 lorries.

\section{Swahili Plant Names}

The demand for Mr. Greenway's modest little "Dictionary of Swahili-Botanical-English Plant Names", having been greater than was expected, has caused the author to prepare a second edition which is nearly three times as thick (Pp. $308+10$ plates. Dar es Salaam: Government Printer, 1940. 4s.). The format is the same, but there have now been added a separate list of botanical and common English names, a large number of Swahili names, and ten pages of diagrams to illustrate the short glossary of botanical terms. We have noted a few trifling misprints : 'Afromomum' for 'Aframomum', 'tripinnate' for 'bipinnate' (diagram), and 'capitula' for 'capitulum', the drawing for which might equally well serve as a model for an improved garden rake. The printing is excellent, and the author is to be congratulated on providing this enlarged edition of a very useful little book for those in East Africa with little knowledge of botany.

\section{Seventh International Congress of Genetics}

THE Proceedings of the Seventh International Congress of Geneties, which was being held in Edinburgh just prior to the outbreak of war, have been issued as a supplementary volume to the Journal of Genetics. The difficulties in holding the Congress and the magnificent manner in which the secretariat overcame many of them has already been commented upon in NATURE. The papers, covering a varied and wide field, are published either in entirety or in summary form, under an alphabetical arrangement of author's names. A subject index to these 331 papers increases the value of these Proceedings for those who desire to know recent thought and work in genetics. The production of such a publication, in present circumstances, deserves particular praise, since the authors of some of the papers had to leave the Congress in a hurry and are now out of reach.

\section{Control of Soil-borne Tomato Diseases}

Partiar sterilization of the soil by heat is one of the most potent methods of control of soil-borne diseases. Amateur growers, however, do not always possess the requisite apparatus, and various chemical treatments have been suggested. Formalin is the most readily available of these, but the liquid has certain disadvantages in practice. W. Brown has briefly reported (Gard. Chron., February 8) good results with an American suggestion to use formalin adsorbed upon an inert carrier such as diatomaceous earth or sawdust. The experiments relate particularly to the damping-off disease of tomatoes caused by Phytophthora fungi, and in some cases a total control of the malady was effected by the use of formalin powder applied to the seed bed when the seed was sown. Such treatment appears to provide a sustained control of damping-off, and not merely to postpone it for a time. 